\title{
Genetic parameters of agronomic characters in Panicum maximum hybrids ${ }^{1}$
}

\author{
Thiago Gomes dos Santos Braz ${ }^{2^{*}}$, Dilermando Miranda da Fonseca ${ }^{3}$, Liana Jank ${ }^{4}$, Marcos Deon \\ Vilela de Resende ${ }^{5}$, Janaina Azevedo Martuscello ${ }^{6}$, Rosangela Maria Simeão ${ }^{4}$
}

\author{
${ }^{1}$ Financial sources: Embrapa, CNPq and Unipasto. \\ 2 Programa de Pós-Graduação em Zootecnia, Universidade Federal de Viçosa. \\ ${ }^{3}$ Departamento de Zootecnia, Universidade Federal de Viçosa. \\ ${ }^{4}$ Laboratório de Citogenética, Embrapa Gado de Corte. \\ ${ }^{5}$ Embrapa Florestas/Universidade Federal de Viçosa. \\ ${ }^{6}$ Departamento de Zootecnia, Universidade Federal de São João del-Rei.
}

\begin{abstract}
This study was carried out with the objective of estimating the genetic parameters of agronomic traits in Panicum maximum hybrids. Genotypes obtained from the crosses between the sexual plants S10 and S12 and cultivars Tanzania and Mombasa were evaluated. The design was an incomplete blocks design with two replicates (clones) and 33 blocks. Each block was constituted by three lines or plots with nine plants each, which were evaluated in six harvests. All the characters presented low broad sense heritabilities for both the individual harvest and for the mean of harvests and a large difference between the heritability and the individual repeatability coefficient, which may be due to the high permanent environmental variance, mainly for forage dry matter and leaf dry matter. On the other hand, the percentage of leaves also presented low repeatability and permanent environmental variance. The genotypic coefficients of variation were high, except for leaf percentage, but they were also associated with high residual coefficients of variation. Both the broad sense heritabilities per harvest and for the mean of harvests were of moderate magnitude for the agronomic traits evaluated in hybrid individuals of $P$. maximum. On the other hand, there is variability for selection of important characters such as total and leaf dry matter yields and selection for leaf percentage needs a greater number of harvests to improve selection efficiency. The genotypes presented great variability for Bipolaris maydis leaf spot incidence and this character can be included in the $P$. maximum breeding program.
\end{abstract}

Key Words: Bipolaris maydis, leaf percentage, leaf yield, mixed models, morpho-agronomic characters, regrowth

\section{Introduction}

Pastures are the basis of cattle production in Brazil, which has around 159.8 million hectares of arable grassland areas (IBGE, 2006) and 212.8 million heads of cattle (IBGE, 2011). These data point out to the great aptitude of the country for cattle production on pasture.

Due to the great potential for cattle production, several research fronts (nutrition, reproductive management, pasture management, among others) have been developed to correct problems of the supply chain and to improve efficiency in the production process. Among them is the improvement of forage plants, stimulated by the possibility of increasing productivity and diversifying pasture.

The diversification by releasing more adapted and competitive forages is fundamental to mitigate problems caused by monoculture (Jank et al., 2011). In this sense, Panicum maximum Jacq. is a species which is an excellent option for diversification and intensification of use of Brazilian pastures, because it is widely diffused among ranchers and

Received December 16, 2011 and accepted November 6, 2012.

Corresponding author: thiagogsbz@hotmail.com

${ }^{*}$ Current address: Departamento de Zootecnia e Extensão Rural, Universidade Federal do Mato Grosso. is considered the most productive forage propagated by seeds in the Brazilian market (Jank et al., 2008).

Forage breeding through selection of introduced accessions is the main method used to release cultivars. However, although easier and faster, this method is finite, since it is based solely on the evaluation of the adaptive capacity of the accessions collected in nature. Therefore, forage breeding through genetic recombination becomes the best option to obtain new, more productive accessions (Valle et al., 2009).

According to Resende (2002), it is necessary to know the genetic control of the traits to be improved to determine the most efficient breeding strategies. Still according to this author, the genetic control of quantitative traits can be represented by all the mechanisms responsible for their inheritance, such as the number of genes that determine it, actions and genetic effects, heritability, repeatability and genetic associations with other characters.

Thus, the objective of this study was to evaluate the genetic parameters of agronomic traits in Panicum maximum hybrids. 


\section{Material and Methods}

The experiment was conducted at Embrapa Gado de Corte in Campo Grande, Mato Grosso do Sul, Brazil, at $20^{\circ} 27^{\prime}$ latitude and $54^{\circ} 57^{\prime}$ longitude. The climate, according to the Köppen classification, is rainy tropical savanna Aw subtype, characterized by an irregular distribution of annual rainfall and the occurrence of a welldefined dry season during the cold months and rainy season during the summer. Climatic data were recorded during the experimental period (Figure 1).

Hybrids of three full-sib progenies of $P$. maximum were evaluated. The individuals were obtained by crossing four parents: the sexual mother plants, S10 and S12, with the apomictic cultivars Mombasa and Tanzania, which were pollen donors. Progeny 1 resulted from the cross between the sexual plant S10 and tanzaniagrass, progeny 2 resulted from the cross between the same sexual plant with mombasagrass and progeny 3 from the cross between the progenitor S12 and tanzaniagrass.

The hybrids were obtained from polycross blocks in May and June 2007, where the mother plants were placed in the middle of $25 \mathrm{~m}^{2}$ plots of the apomictic progenitors so as to increase pollen density and reduce selfing. Seeds harvested from the mother plants were germinated in December 2007 and transplanted into plastic bags in a greenhouse in February 2008, where they remained until they presented sufficient growth to be transplanted to the field in November 2008.

After establishment, there were 114 hybrids from progeny 1; 167 hybrids from progeny 2; and 45 from progeny 3 . The 326 individuals were cloned by clump division and planted in a clonal test.

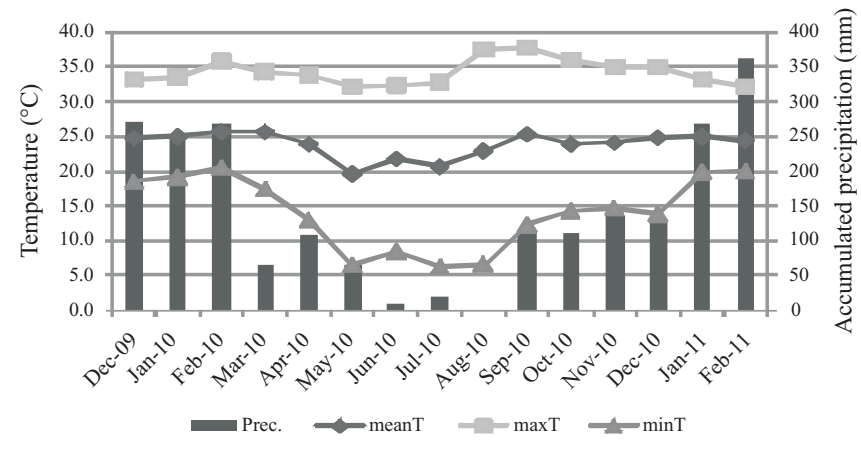

Source: weather station of Embrapa Gado de Corte.

Figure 1 - Accumulated rainfall (Prec.), mean (meanT), maximum $(\max \mathrm{T})$ and minimum $(\mathrm{minT})$ temperatures recorded during the experimental period.
The soil sampled from the 0 to $20 \mathrm{~cm}$ layer of the experimental area was analyzed and presented the following chemical characteristics: $\mathrm{pH}$ in water $(1: 2.5$ ratio $)=$ 5.10; P-Mehlich ${ }^{-1}=2.61 \mathrm{mg} / \mathrm{dm}^{3} ; \mathrm{K}^{+}=17.70 \mathrm{mg} / \mathrm{dm}^{3}$; $\mathrm{Ca}^{2+}=6.56 \mathrm{cmol}_{\mathrm{c}} / \mathrm{dm}^{3} ; \mathrm{Mg}^{2+}=1.62 \mathrm{cmol}_{\mathrm{c}} / \mathrm{dm}^{3} ; \mathrm{Al}^{3+}=0.11$ $\mathrm{cmol}_{\mathrm{c}} / \mathrm{dm}^{3} ; \mathrm{H}+\mathrm{Al}=3.01 \mathrm{cmol}_{\mathrm{c}} / \mathrm{dm}^{3}, \mathrm{~V} \%=57.17 ; \mathrm{m} \%=$ 2.70; and organic matter $=3.24 \mathrm{dag} / \mathrm{kg}$. According to the results of this analysis, $120 \mathrm{~kg} / \mathrm{ha}$ of $\mathrm{P}_{2} \mathrm{O}_{5}$ were applied as superphosphate and $40 \mathrm{~kg} / \mathrm{ha}$ of $\mathrm{K}_{2} \mathrm{O}$ as potassium chloride during the establishment of the plots in the field. The area where the experiment was established was prepared by the conventional method, by plowing, applying lime and then harrowing at the end of the rainy season prior to transplanting the seedlings to the field. During the experimental period, plants received annually $100 \mathrm{~kg} / \mathrm{ha} \mathrm{N}$, $100 \mathrm{~kg} / \mathrm{ha}$ of $\mathrm{K}_{2} \mathrm{O}$ and $100 \mathrm{~kg} / \mathrm{ha}$ of $\mathrm{P}_{2} \mathrm{O}_{5}$.

An incomplete block design was used with two replications and a total of 33 blocks. Each block consisted of three rows or plots with nine plants per row. Each row corresponded to one of the above progenies. At the border mombasagrass plants were used. Spacing was one meter between plants within the row and between rows.

The hybrids were managed through harvests at a height of $25 \mathrm{~cm}$ from the ground level performed on January 26th, March 8th, June 5th, October 10th, November 18th, December 29th, 2010 and February 3rd, 2011. The harvest performed on June 5 th was not used in the analysis because it occurred right after flowering of the hybrids, where seeds were also harvested for future studies. In each harvest, forage was collected, weighed and a sample was made. Samples were separated into the morphological components: leaf blades, stems and sheaths and dead forage, which were then dried for determination of dry weight and their relative participation in the morphological composition of the samples. Thus, the following agronomic characteristics were evaluated: total dry mass (TDM - g/plant), leaf percentage (\%L), leaf dry mass (LDM - g/plant) and stem + sheaths (SDM - g/plant). The $\% \mathrm{~L}$ was estimated using the ratio of the dry mass of leaf blades and the sum of the dry mass of blades and stems and sheaths from the morphological separation, i.e., the quotient of the dry mass of leaf blades and herbage green dry matter. The following characteristics were also evaluated: plant height $(\mathrm{cm})$, regrowth and incidence of leaf spot caused by the fungus Bipolaris maydis (IBM).

The height was measured with a ruler the day before each harvest. Evaluations of regrowth, in turn, were performed seven days after each harvest. This value includes two characteristics: density and speed. Density of regrowth was visually estimated by assigning scores 1 to 5 , where 1 corresponded to $0-20 \%$ of regrown tillers and regrowth 5 
corresponded to $80-100 \%$ of regrown tillers. The speed of regrowth was determined by assigning values -1 (slow), 0 (middle) and 1 (high). The sum of the two gave the value of the plant regrowth, which varied from 0 to 6 .

For the evaluation of leaf spots caused by B. maydis (IBM), a subjective evaluation was also used, with scores from 1 to 5 , with 1 representing 0 to $20 \%$ incidence and 5 corresponding to 80 to $100 \%$ of incidence. This evaluation was also done the day before the plants were harvested.

To facilitate the discussion of the results, the characters were divided in yield traits (TDM, SDM and LDM) and morpho-agronomic traits (\%L, height, regrowth and IBM). Variance components and genetic parameters for each trait evaluated in the hybrid individuals were estimated by the linear mixed model:

$$
y=X m+Z g+W p+T b+Q s+e
$$

where $\mathrm{y}=$ data vector; $\mathrm{m}=$ vector of the effects of replication-measurement combinations (assumed to be fixed) added to the overall mean; $g$ = vector of genotypic effects of individual (assumed to be random); $p=$ vector of plots effects (assumed to be random); $b=$ vector of blocks effects (assumed to be random); $\mathrm{s}=$ vector of permanent environmental effects (random); and $\mathrm{e}=$ vector of errors or residues (random). The capital letters represent matrices of incidence for these effects.

To estimate the heritability of mean of harvests from each individual, the following formula was used:

$$
h_{m}^{2}=\frac{m h_{g}^{2}}{1+(m-1) r}
$$

where $\mathrm{h}_{\mathrm{m}}^{2}=$ broad sense mean heritability; $\mathrm{m}=$ number of measures; $\mathrm{h}_{\mathrm{g}}^{2}=$ broad sense individual heritability per harvest; and $\mathrm{r}=$ individual repeatability coefficient.

The significance of genetic parameters was tested using the likelihood ratio test with the chi-square statistics at 5 and $1 \%$ probability.

The genotypic coefficient of variation was estimated as follows:

$$
C V g(\%)=\frac{100 \times \sqrt{G V}}{\mu}
$$

where $\mathrm{CVg}(\%)=$ coefficient of genotypic variation; $\mathrm{GV}=$ genotypic variance among hybrids; and $\mu=$ overall mean of the character.

The coefficient of residual variation was estimated by:

$$
C V r(\%)=\frac{100 \times \sqrt{V r}}{\mu}
$$

where $\mathrm{CVr}(\%)=$ residual or environmental coefficient of variation; $\mathrm{Vr}=$ residual variation component; and $\mu=$ overall mean of the character.
With the ratio between $\mathrm{CVg}(\%)$ and $\mathrm{CVr}(\%)$ the parameter ratio $\mathrm{CVg} / \mathrm{CVr}$ was obtained.

The selective accuracy $\left(\breve{r}_{\breve{g} g}\right)$ was estimated according to Resende (2002):

$$
\breve{r}_{\check{g} g}=\left[\frac{1}{1+\left(V_{r} / b\right) / V_{g}}\right]^{1 / 2}
$$

All analyses were performed using Statistical System and Computerized Genetic Selection via Linear Mixed Models, Selegen - REML/BLUP (Resende, 2007).

\section{Results and Discussion}

The components of genotypic variance, variance among plots and permanent environmental variance were significant $(\mathrm{P}<0.05)$ for all variables evaluated, except for $\% \mathrm{~L}$, where the permanent environmental component was not significant $(\mathrm{P}>0.05)$ (Table 1).

The occurrence of permanent environmental variance is probably associated with the existence of microclimate or soil conditions that favored the development of certain plants. In this experiment, the permanent environmental variance was probably due to the occurrence of mortality after the establishment of the experimental area. Thus, plants living near these sites had different performance and contributed to the inflation of the permanent environmental variance.

The average forage production per harvest was $916.1 \mathrm{~g} /$ plant, which represents the total production of approximately $55 \mathrm{t} / \mathrm{ha}$ in six harvests, $13.4 \mathrm{t} / \mathrm{ha}$ year of herbage dry matter and $10.6 \mathrm{t} / \mathrm{ha}$ of leaf dry matter. These results are in agreement with those of Resende et al. (2004), who observed forage yield of $55.04 \mathrm{t} / \mathrm{ha}$ year, dry matter yield of $9.84 \mathrm{t} / \mathrm{ha}$ year and leaf yield of $8.06 \mathrm{t} / \mathrm{ha}$ year in full-sib progenies of $P$. maximum.

Overall, low heritability coefficients of individual broad sense heritability per harvest were observed for yield traits in P. maximum hybrids (Table 2). According to Resende et al. (2004), the magnitude of heritability is of utmost importance in the breeding program, because it determines the degree of difficulty in improving the character in question and indicates the most efficient method to be used.

Among the yield characters, TDM and LDM had the highest heritability coefficients per harvest: 0.1952 and 0.2023 , respectively (Table 2). It can be observed that they were within the expected range for quantitative traits, which is from 0.10 to 0.50 . These results are confirmed by those of Resende et al. (2004), who obtained coefficients of 0.14 and 0.16 for the characters TDM and LDM, respectively, 
Table 1 - Estimated variance components for the yield and morpho-agronomic traits and incidence of B. maydis (IBM) in Panicum maximum hybrids

\begin{tabular}{|c|c|c|c|c|c|c|}
\hline \multirow[b]{2}{*}{ Traits } & \multicolumn{6}{|c|}{ Variance components } \\
\hline & Genotypic variance & $\begin{array}{l}\text { Variance among } \\
\text { plots }\end{array}$ & $\begin{array}{l}\text { Variance among } \\
\text { blocks }\end{array}$ & $\begin{array}{c}\text { Permanent environmental } \\
\text { variance }\end{array}$ & Residual variance & Phenotypic variance \\
\hline Total dry matter & $3409.8464 * *$ & $2689.0540 * *$ & $50.2876 \mathrm{~ns}$ & $4209.6445 * *$ & 7106.1349 & 17464.9675 \\
\hline Leaf dry matter yield & $2184.6652 * *$ & $1662.4970 * *$ & $25.4210 \mathrm{~ns}$ & $2607.5245 * *$ & 4316.6631 & 10796.7708 \\
\hline Stem dry matter yield & $132.7296^{* *}$ & $72.1320 * *$ & $3.7200 \mathrm{~ns}$ & $32.0381 *$ & 637.9395 & 878.5591 \\
\hline Leaf percentage & $5.8285^{* *}$ & $3.3299 \mathrm{~ns}$ & $0.0807 \mathrm{~ns}$ & $0.2155 \mathrm{~ns}$ & 30.0710 & 39.5255 \\
\hline Plant height & $63.0235 * *$ & $90.1194 * *$ & $0.7010 \mathrm{~ns}$ & $32.2435 * *$ & 89.1097 & 275.1972 \\
\hline Regrowth & $0.3101 * *$ & $0.1690 * *$ & $0.0510 \mathrm{~ns}$ & $0.1512 *$ & 0.9028 & 1.5841 \\
\hline IBM & $0.4598 * *$ & $0.4783 * *$ & $0.0026 \mathrm{~ns}$ & $0.0309 * *$ & 0.5035 & 1.4751 \\
\hline
\end{tabular}

**, * Significant at 1 and 5\% probability by the likelihood ratio test using X-square statistics, respectively; ns - not significant.

in full-sib progenies evaluated in individual harvests, as in this study.

The character SDM had the lowest heritability estimated among the yield traits (Table 2). This is probably due to the large residual variation coefficient observed for this variable (Table 2). The components of variance among blocks and permanent environment contributed little to the variation observed for this variable. These results point out to the great influence of temporary environmental factors (climate variation between harvests, for example) on the SDM and small genetic control of this variable. Similar results were observed by Jank et al. (2009) in genotypes evaluated on national network trials in several locations.

The heritability coefficients of mean harvests of yield traits were higher than the heritability coefficients for

Table 2 - Genetic parameters for the characters total (TDM), leaf (LDM) and stem (SDM) dry matter yields in Panicum maximum hybrids

\begin{tabular}{|c|c|c|c|}
\hline \multirow{2}{*}{ Parameters } & \multicolumn{3}{|c|}{ Yield characters } \\
\hline & TDM $(\mathrm{g})$ & $\operatorname{LDM}(\mathrm{g})$ & $\operatorname{SDM}(\mathrm{g})$ \\
\hline Overall mean & 224.1 & 176.0 & 29.3 \\
\hline$h_{g}^{21}$ & 0.1952 & 0.2023 & 0.1511 \\
\hline$r^{2^{5}}$ & 0.5931 & 0.6002 & 0.2739 \\
\hline $\mathrm{h}_{\mathrm{m}}^{23}$ & 0.2953 & 0.3034 & 0.3826 \\
\hline $\mathrm{C}_{\text {parc }}^{2}{ }^{4}$ & 0.1540 & 0.1540 & 0.0821 \\
\hline $\mathrm{C}_{\text {bloc }}^{2}{ }^{5}$ & 0.0029 & 0.0024 & 0.0042 \\
\hline $\mathrm{C}_{\text {perm }}^{2}{ }^{6}$ & 0.2410 & 0.2415 & 0.0365 \\
\hline$\% \mathrm{CVg}^{7}$ & 26.06 & 26.55 & 39.28 \\
\hline$\% \mathrm{CVr}^{8}$ & 37.61 & 37.32 & 86.11 \\
\hline $\mathrm{CVg} / \mathrm{CVr}^{9}$ & 0.6927 & 0.7114 & 0.4561 \\
\hline Accuracy & 0.7998 & 0.7092 & 0.5420 \\
\hline
\end{tabular}

\footnotetext{
${ }^{1}$ Individual broad sense heritability per harvest.

${ }^{2}$ Individual repeatability coefficient.

${ }^{3}$ Heritability of the mean of harvests.

${ }^{4}$ Coefficient of determination of plots.

${ }^{5}$ Coefficient of determination of blocks.

${ }^{6}$ Coefficient of determination of the permanent environment

${ }^{7}$ Coefficient of genotypic variance.

${ }^{8}$ Coefficient of residual variation.

${ }^{9}$ Ratio between genotypic and residual coefficients of variation.
}

individual harvest, but were also of low magnitude (Table 2). In this sense, the characters TDM and LDM had similar heritability, ranging between 0.29 and 0.30 . The character SDM showed heritability means of 0.3826 , indicating that greater gains with their selection can be obtained through the use of heritability of the mean of harvests.

The major differences observed between the individual heritability per harvest and the mean of harvests can be attributed to the lower mean phenotypic variation in the denominator of the heritability due to the decrease in the mean residual variance from the use of repeated measures (harvests). The heritabilities of means observed by Resende et al. (2004) were higher than those obtained in this study, with coefficients of 0.44 and 0.47 for TDM and LDM, respectively in one year of evaluation and 0.68 and 0.72 for a three-year evaluation. In other studies reported by Jank et al. (2008), involving the evaluation of accessions and hybrids of $P$. maximum, the heritability of means assumed greater magnitude with values between 0.40 and 0.68 and from 0.31 to 0.76 for TDM and LDM, respectively.

Among the morpho-agronomic characters, higher heritability coefficients for individual harvests were estimated for IBM, height and regrowth, which were $0.3117,0.2290$ and 0.1958 , respectively (Table 3 ). These coefficients could also be classified as of low magnitude.

The individual heritability per harvest for the character IBM was the largest among traits in the experiment. This variable has been receiving greater importance in P. maximum breeding, because of the occurrence of leaf spot caused by the helmintosporium $B$. maydis in tanzaniagrass pastures. According to Martinez et al. (2010) this pathogen is able to impair the production and tillering of the forage, which are fundamental characteristics for the sustainability of the pasture. In this sense the selection of more resistant plants that present greater quantity of favorable characteristics and lower incidence becomes important for the diversification of $P$. maximum pastures. 
The heritability coefficients of means of morphoagronomic characters were also of low magnitude, and the characters IBM and \%L had higher coefficients (Table 2).

Special attention should be drawn to the character $\% \mathrm{~L}$, which had its heritability substantially improved by the evaluation of the mean of harvests (Table 2). This procedure probably attenuated the variation in the repeated measures and showed to be a way of increasing the efficiency of selection of that character, which is among the ones of highest importance in P. maximum breeding. According to Jank et al. (2008), heritability values for the mean of the character $\% \mathrm{~L}$ have been reported in the literature between 0.12 and 0.78 , most of them assuming values below 0.21 . Thus, one can conclude that the results observed in this study are consistent with those from the literature and indicate that the character $\% \mathrm{~L}$ has low heritability per harvest, and strategies to increase selective efficiency are necessary, such as increase in the number of replications and the number of repeated measures.

Note that the estimates of heritability per harvest and mean of harvests in general assumed values below 0.5, indicating that the gains from selection in the breeding program of the evaluated population may be limited. However, these results are probably due to the genetic proximity between individuals evaluated that come from improved populations, or even due to the occurrence of a large residual variation.

The repeatability coefficients of yield character assumed medium to high magnitude values (Table 2); the

Table 3 - Genetic parameters estimated for the morpho-agronomic traits and incidence of Bipolaris maydis (IBM) in individual hybrids of Panicum maximum

\begin{tabular}{|c|c|c|c|c|}
\hline \multirow{2}{*}{ Parameters } & \multicolumn{4}{|c|}{ Morpho-agronomic characters } \\
\hline & $\% \mathrm{~F}$ & Plant height & Regrowth & IBM \\
\hline Overall mean & 88.89 & 74.6874 & 3.1705 & 0.8060 \\
\hline $\mathrm{h}_{\mathrm{g}}^{2} 1$ & 0.1475 & 0.2290 & 0.1958 & 0.3117 \\
\hline$r^{2}$ & 0.2392 & 0.6762 & 0.4301 & 0.6587 \\
\hline $\mathrm{h}_{\mathrm{m}}^{23}$ & 0.4030 & 0.3024 & 0.3158 & 0.4288 \\
\hline $\mathrm{C}_{\text {parc }}^{2}{ }^{4}$ & 0.0842 & 0.3275 & 0.1067 & 0.3243 \\
\hline $\mathrm{C}_{\text {bloc }}^{2}{ }^{5}$ & 0.0020 & 0.0025 & 0.0322 & 0.0018 \\
\hline $\mathrm{C}_{\text {perm }}^{2}{ }^{6}$ & 0.0055 & 0.1172 & 0.0955 & 0.0210 \\
\hline$\% \mathrm{CVg}^{7}$ & 2.72 & 10.63 & 17.56 & 84.13 \\
\hline$\% \mathrm{CVr}^{8}$ & 6.17 & 12.64 & 29.97 & 88.04 \\
\hline $\mathrm{CVg} / \mathrm{CVr}^{9}$ & 0.4403 & 0.8410 & 0.5861 & 0.9556 \\
\hline Accuracy & 0.5286 & 0.7654 & 0.6382 & 0.8039 \\
\hline
\end{tabular}

${ }^{1}$ Individual broad sense heritability per harvest.

${ }^{2}$ Individual repeatability coefficient.

${ }^{3}$ Heritability of the mean of harvests.

${ }^{4}$ Coefficient of determination of plots.

${ }^{5}$ Coefficient of determination of blocks.

${ }^{6}$ Coefficient of determination of the permanent environment

${ }^{7}$ Coefficient of genotypic variance.

${ }^{8}$ Coefficient of residual variation.

${ }^{9}$ Ratio between genotypic and residual coefficients of variation. highest estimated for TDM (0.5931) and LDM (0.6002). Martuscello et al. (2007), evaluating the repeatability in half-sib progenies of $P$. maximum by means of multivariate methods and by analysis of variance observed similar ratios to this study for TDM and higher for LDM. According to these authors, the repeatability coefficients ranged between 0.5165 and 0.6182 and between 0.7038 and 0.8611 for the characters TDM and LDM, respectively.

The character SDM, on the other hand, had the lowest coefficient of repeatability estimated among yield traits (Table 2). The inclusion of this character in the breeding program of $P$. maximum may help reduce the share of this component in the morphological composition of the forage and thus improve the nutritional value and consumption by grazing animals. However, this must be evaluated for a greater number of harvests and longer evaluation periods for a greater selective efficiency.

Among the morpho-agronomic characters, higher repeatabilities were estimated for height and IBM (Table 3). These results indicate that the efficiency in the selection of resistant individuals for leaf spot caused by B. maydis can be achieved with fewer observations. Lédo et al. (2008) observed repeatability coefficients ranging between 0.603 and 0.748 for plant height in P. maximum genotypes.

The character $\%$ L showed low repeatability (Table 3 ) and similar to the value of the broad sense individual heritability. This result indicates that the permanent environmental effect of this character is low and that large numbers of repeated measures should be performed to increase precision in selection based on repeatability. Repeatability expresses the maximum value that the broad sense heritability can achieve, since it expresses the proportion of phenotypic variance that is attributed to genetic differences confounded with the permanent effects that act on the cultivar or progeny. In this context, the repeatability coefficient will approach the heritability coefficient when the variance provided by the permanent effects of the environment is reduced.

The differences between the coefficients of heritability and repeatability observed for the characters TDM and LDM indicate a large share of permanent environmental effect. In fact, these characters also present the highest permanent environmental coefficients of determination, which were 0.2410 and 0.2415 , respectively (Table 2). Moreover, for the characters $\mathrm{SDM}$ and $\% \mathrm{~L}$, proximity between the coefficients of heritability and repeatability and low coefficient of determination of permanent environment were observed (Tables 1 and 2). Character $\% \mathrm{~L}$ is of great importance in forage breeding, and due to its low repeatability, it requires a greater number of repeated measures for increasing selective efficiency. However, 
strategies such as simultaneous selection through correlated traits of high heritability can also be considered an alternative for its increase.

The differences between the coefficients of heritability and repeatability of morpho-agronomic characters plant height, regrowth and IBM were also high (Table 3). However, for the characters height and IBM, a greater participation of the component of variance among plots occurred, while for regrowth, the components of variance among blocks and permanent environment also contributed to increase the differences between the individual heritability and repeatability (Table 3 ).

The genotypic coefficients of variation (CVg) of yield characters indicated the occurrence of genotypic variability among hybrids (Table 2) and ranged from 26.06\% for TDM, and $39.28 \%$ for SDM. Genetic variability is an indispensable condition for selection to be performed (Falconer \& Mackay, 1996). Leaf dry matter has been used as a central feature in forage breeding, especially for bunch grasses, and presented CVg of $26.55 \%$.

Genotypic variation coefficients of lesser magnitude were observed for morpho-agronomic characters $\% \mathrm{~L}$, height and regrowth, which were of 2.72 , 10.63 and $17.56 \%$ (Table 3 ). The association of low repeatability and low $\mathrm{CVg}$ indicates that the population under study has low genetic variability for $\% \mathrm{~L}$ and that the chances of gain from selection are reduced.

In general, the low $\mathrm{CVg}$ attributed to the characters $\% \mathrm{~L}$, regrowth and height can be explained by the genetic proximity among evaluated hybrids. Daher et al. (2004) observed genotypic variation coefficients of 6.66 and 6.86 for dry matter yield and plant height, respectively, for clones of elephant grass.

The highest $\mathrm{CVg}$ was observed for the character IBM $(84.13 \%)$ (Table 3$)$. The great variability observed was probably caused by crossing the susceptible plant, as tanzaniagrass, and the progenitors $\mathrm{S} 10$ and $\mathrm{S} 12$, resistant to leaf spot. These results indicate that IBM has great potential to be used in the $P$. maximum breeding program.

For IBM, a high coefficient of residual variation $(\mathrm{CVr}=$ $88.04 \%$ ) was also recorded; however, the sole observation of this coefficient does not allow for an adequate evaluation of the experimental quality, so it is necessary to consider also the genotypic coefficient of variation, through the $\mathrm{CVg} / \mathrm{CVr}$ ratio. In this sense, IBM was the variable which presented the highest $\mathrm{CVg} / \mathrm{CVr}$ ratio, which reached a value close to a unit, with selective accuracy greater than 0.80 , indicating a high possibility of gain from selection for this trait.
High coefficients of residual or environmental variation $(\mathrm{CVr})$ were observed among yield traits, especially for SDM (86.11\%). This high value of $\mathrm{CVr}$ led to a low $\mathrm{CVg} / \mathrm{CVr}$ ratio value and moderate accuracy $(r=0.54$ - Table 2). According to Resende \& Duarte (2007), the accuracy of this magnitude is unsuitable for the process of selection of superior genotypes in breeding for the trait in question. It is recommended to increase the number of replications in future evaluations of $P$. maximum hybrids to increase selective accuracy of superior genotypes for SDM.

The observation of high coefficients of variation led to residual values below the unit for the $\mathrm{CVg} / \mathrm{CVr}$ ratio (Table 2) for both SDM and characters TDM and LDM. According to the report by Vencovsky (1987), $\mathrm{CVg} / \mathrm{CVr}$ ratio values exceeding a unit are suitable for experimentation with corn, which is based on a small number of replications. However, Resende \& Duarte (2007) reviewed this recommendation and showed that even with values of $\mathrm{CVg} / \mathrm{CVr}$ ratio below one, it is possible, if an adequate number of replications is used, to achieve a selective accuracy equal to or greater than 0.70 , usually recommended for breeding experiments. These accuracy values were obtained for the characters TDM and LDM (Table 2), which allows predicting the genotypic values of the hybrids and to select the superior ones. Low $\mathrm{CVg} / \mathrm{CVr}$ ratio was also observed by Daher et al. (2004), for dry matter production of clones of elephant grass, where the $\mathrm{CVg} / \mathrm{CVr}$ ratio was 0.1424 ; however, the authors did not report the values of accuracy.

The observation of high CVr for most variables may have implied in a decrease in the coefficient of heritability per harvest and mean of harvests, which were found to be below the values reported in the literature.

The CVr of morpho-agronomic characters was generally low, especially for the characters $\% \mathrm{~L}$ and height (Table 3 ). In this sense, $\mathrm{CVg} / \mathrm{CVr}$ ratios closer to a unit were observed for these characters, as well as high accuracy for height. Thus, breeding strategies that provide greater variability in the crosses may be regarded as options for obtaining genotypic variability for the character $\% \mathrm{~L}$ and consequently making the $\mathrm{CVg} / \mathrm{CVr}$ ratio and accuracy more favorable.

The $\mathrm{CVg} / \mathrm{CVr}$ ratio below 1 for all the variables studied indicates that the influence of environmental factors on the agronomic traits of the population of $P$. maximum hybrids is great. The recommendation of Resende \& Duarte (2007) to solve this issue is to increase the number of replications in experimentation and number of evaluations over several years, leading to increased selective accuracy. According to Resende \& Duarte (2007), selective accuracy is the most suitable parameter for evaluating the experimental quality 
in breeding and should assume values greater than 0.70 . Also according to these authors, to achieve such accuracy, at least five replications would be necessary in the current experiment.

\section{Conclusions}

Both the individual broad sense heritability per harvest and the heritability of mean of harvests of agronomic traits are of low magnitude in Panicum maximum hybrids. There is variability for selection of characters of great importance for the breeding program such as total and leaf dry matter yields and that the trait percentage of leaves requires a greater number of harvests to be efficiently improved. The genotypes present great variability for incidence of leaf spot caused by Bipolaris maydis and this trait may be included in the breeding program of this species.

\section{References}

DAHER, R.F.; MALDONADO, H.; PEREIRA, A.V. et al. Estimativas de parâmetros genéticos e de coeficientes de repetibilidade de caracteres forrageiros em clones de capim-elefante (Pennisetum purpureum Schum.). Acta Scientiarum Agronomy, v.26, n.4, p.483-490, 2004.

FALCONER, D. S.; MAKCAY, T. F. C. Introduction to quantitative genetics. 4.ed. Essex: Longman, 1996. 464p.

INSTITUTO BRASILEIRO DE GEOGRAFIA E ESTATÍSTICA IBGE. Censo agropecuário. [2006]. Available at: $<\mathrm{http} / / \mathrm{www}$. sidra.ibge.gov.br/bda/pecua/default.asp?t $=1 \& z=t \& o=24 \& u 1=1 \& u 2=$ $1 \& u 3=1 \& u 4=1 \& u 5=1 \& u 6=1 \& u 7=1>$. Accessed on: April 15, 2011.

INSTITUTO BRASILEIRO DE GEOGRAFIA E ESTATÍSTICA - IBGE. Pesquisa pecuária municipal. [2011]. Available at: $<$ http://www.sidra.ibge.gov.br/bda/pecua/default.asp?t=2\&z=t\&o
$=24 \& u 1=1 \& u 2=1 \& u 3=1 \& u 4=1 \& u 5=1 \& u 6=1 \& u 7=1>$. Accessed on: December 17, 2012.

JANK, L.; RESENDE, R.M.S.; VALENTIM, J.F. et al. Análise genética de Panicum maximum Jacq. em rede nacional. In: CONGRESSO BRASILEIRO DE MELHORAMENTO DE PLANTAS, 2009, Guarapari. Anais... Vitória: Incaper, 2009. (CD-ROM).

JANK, L.; RESENDE, R.M.S.; VALLE, C.B. et al. Melhoramento genético de Panicum maximum. In: RESENDE, R.M.S.; VALLE, C.B.; JANK, L. (Eds.) Melhoramento de forrageiras tropicais. 1.ed. Campo Grande: Embrapa, 2008. p.55-87.

JANK, L.; VALLE, C.B.; RESENDE, R.M.S. Breeding tropical forages. Crop Breeding and Applied Biotechnology, Special edition 1, p.27-34, 2011.

LÉDO, F.J.S.; PEREIRA, A.V.; SOBRINHO, F.S. et al. Estimativas de repetibilidade para caracteres forrageiros em Panicum maximum. Ciência e Agrotecnologia, v.32, n.4, p.1299-1303, 2008.

MARTINEZ, A.S.; FRANZENER, G.; STANGARLIN, J.R. Dano causado por Bipolaris maydis em Panicum maximum cv. Tanzânia. Semina: Ciências Agrárias, v.31, n.4, p.863-870, 2010.

MARTUSCELLO, J.A.; JANK, L.; FONSECA, D.M. et al. Repetibilidade de caracteres agronômicos em Panicum maximum Jacq. Revista Brasileira de Zootecnia, v.36, n.6, p.1975-1981, 2007 (supl.).

RESENDE, M.D.V. Genética biométrica e estatística no melhoramento de plantas perenes. Brasília: Embrapa Informação Tecnológica, 2002.975p.

RESENDE, M.D.V. SELEGEN-REML/BLUP Sistema estatístico e seleção genética computadorizada via modelos lineares mistos. Colombo: Embrapa Florestas, 2007. 360p.

RESENDE, M.D.V.; DUARTE, J.B. Precisão e controle da qualidade de experimentos para avaliação de cultivares. Pesquisa Agropecuária Tropical, v.37, n.3, p.182-194, 2007.

RESENDE, R.M.S.; JANK, L.; VALLE, C.B. et al. Biometrical analysis and selection of tetraploid progenies of Panicum maximum using mixed models methods. Pesquisa Agropecuária Brasileira, v.39, n.4, p.335-341, 2004.

VALLE, C.B.; JANK, L.; RESENDE, R.M.S. O melhoramento de forrageiras tropicais no Brasil. Revista Ceres, v.56, n.4, p.460-472, 2009.

VENCOVSKY, R. Herança quantitativa. In: PATERNIANI, E.; VIEGAS, G.P. (Eds.) Melhoramento e produção de milho. 2.ed. Campinas: Fundação Cargill, 1987. p.137-214 